\title{
Productive and Reproductive Performances of Indigenous Sheep in Ethiopia: A Review
}

\author{
Shashie Ayele ${ }^{*}$, Mengistu Urge ${ }^{2}$ \\ ${ }^{1}$ Department of Animal Sciences, College of Agriculture and Natural Resources, Debre Markos University, Debremarkos, Ethiopia \\ ${ }^{2}$ School of Animal and Range Sciences, College of Agriculture and Environmental Sciences, Haramaya University, Dire Dawa, \\ Ethiopia \\ Email: *aklileshashie@gmail.com
}

How to cite this paper: Ayele, S. and Urge, M. (2019) Productive and Reproductive Performances of Indigenous Sheep in Ethiopia: A Review. Open Journal of Animal Sciences, 9, 97-120.

https://doi.org/10.4236/ojas.2019.91009

Received: September 28, 2018

Accepted: January 7, 2019

Published: January 10, 2019

Copyright (c) 2019 by author(s) and Scientific Research Publishing Inc. This work is licensed under the Creative Commons Attribution International License (CC BY 4.0).

http://creativecommons.org/licenses/by/4.0/

\begin{abstract}
Sheep in Ethiopia is among the major economically important livestock species in the country, playing a significant role to the livelihood of resource-poor farmers and pastoralists. A number of research works were done in the past which evaluate and improve the performance of indigenous sheep in Ethiopia. However, compiled information concerning the production and reproduction potential of indigenous sheep in the country is not available. In this paper, performance of major production and reproduction traits of indigenous sheep is reviewed and discussed. The information presented in this review indicated that, 16 to $126 \mathrm{~g} / \mathrm{d}$ average daily gain, $7-18 \mathrm{~kg}$ hot carcass weight and dressing percentage of $34 \%$ to $49 \%$ (slaughter body weight basis) at 18 - $26 \mathrm{~kg}$ slaughter body weight have been recorded for Ethiopian sheep breeds fed various type of basal and supplement diets. These parameters showed variation within a breed and among breeds in various feeding trials and they increased as the level of supplement increases. However, despite sizeable information upon the response of sheep to various types of supplementary feeding, their full growth and other production potential of the majority of sheep breeds of the country are not well studied. Therefore, in future research work, emphasis should be given to explore the genetic potential of various production traits of sheep breeds of the country. Regarding the level of reproduction, 11 to 16 month age at first lambing (for most sheep breeds) and 7 to 10 month lambing intervals have been reported by various authors. The litter size result (1.01 to 1.7 lambs) showed that, there is high capability of Ethiopian sheep to give multiple births. The average pre-weaning mortality rate for most Ethiopian sheep breeds vary from $8 \%$ to $56 \%$, which indicated that mortality is a major constraint that affects productivity of sheep in Ethiopia. Generally from the previous results it can be concluded that there is high
\end{abstract}


variability within a breed and among Ethiopian sheep breeds in various production and reproduction traits. This implicates the presence of huge opportunity to improve these traits through improved management and selection.

\section{Keywords}

Carcass Production, Ethiopia, Growth Rate, Lambing Interval, Indigenous Sheep

\section{Introduction}

Ethiopia inhabits the second largest sheep population in Africa, numbering about 30.7 million heads [1]. The sheep breeds are widely distributed in divers ecology of the country ranging from sub-alpine to arid lowlands [2], ethnic communities and production systems [3]. The country owns fourteen traditional sheep populations that are clustered into four major groups of sheep types based on their tail type namely, short fat-tailed, long fat tailed, thin-tailed, and fat-rumped tailed sheep [4]. In the study by Solomon et al. [2] using microsatellite DNA marker, nine breeds and six genetically distinct sheep breed groups were identified in the country being distributed in different agro-ecologies, production systems and ethnic groups. According to the study, variation among Ethiopian sheep breeds was not because of variation in their ecological locations or in the breeding management practiced by the different communities who rear them but it was due to geographical distances between the breeds.

In Ethiopia, $75 \%$ of the sheep population is produced in mixed crop-livestock production and the remaining $25 \%$ are kept in pastoral and agro-pastoral production systems. They are managed under low input extensive production systems and produced the lowest carcass weight compared to other east African countries. The purpose of keeping sheep is vary from area to area due to ecological, economic, and cultural factors [5] however, they are mainly maintained for fulfilling multiple roles, such as cash income, meat, milk, skin, wool, manure, security, gifts and religious rituals [6] [7].

Despite of their large number and contributions, efforts made so far to improve the productivity of indigenous sheep were very little. The average carcass weight of Ethiopian sheep $(10 \mathrm{~kg})$ is the lowest relative to all countries and the world average, by about $1 \mathrm{~kg}, 3 \mathrm{~kg}$ and $6 \mathrm{~kg}$ from east African countries, least developed countries and world, respectively [8]. The major factors attributed to this low productivity are poor nutrition, genotype, inadequate indigenous breed utilizations for production, limited knowledge of the husbandry practices, and environment [3] [9]. A lot of researches were conducted in the country for academic and for development purposes in the past to evaluate and improve the productivity of the indigenous Ethiopian sheep. However, the information generated from such research works are not compiled and made available to beneficiaries. The purpose of this paper is, therefore, to review and document the 
potential of indigenous Ethiopian sheep for major production and reproduction traits under different management conditions and to highlight future research priorities.

\section{Response of Ethiopian Sheep to Supplement Feeding}

\subsection{Growth Response}

To evaluate a sheep for meat production potential, growth performance is an important character which determines the overall productivity of the flock and the economic return from sheep production enterprise. Although heredity dictates the maximum amount of growth and development, nutrition along with other environmental factors govern the actual rate of growth and extent to which development is attained [10] [11]. Nevertheless any additional input than required for normal physiological needs may not induce growth beyond the genetic potential of the animal [12].

Washera sheep supplemented with $300 \mathrm{~g} /$ day of different forms of white lupin to Rhodes grass hay basal diet gained between 16 to $25 \mathrm{~g} /$ day [13]. This is lower than the values reported in other studies of the same sheep (Table 1). A higher average daily gain (ADG) of $73-91 \mathrm{~g} /$ day has been found in a study conducted by Likawent et al. [14] using Washera breed supplemented with sweet blue lupin seed as a substitute for concentrate mix (453 g/day/head). Yearling Washera sheep grazing natural pasture supplemented with 300 to $700 \mathrm{~g} /$ day (grass pea and maize grain at a ratio of 4:1 mixture) are reported to grow at the rate of 88 $126 \mathrm{~g} /$ day [12]. The authors recommend feeding $500 \mathrm{~g} /$ day concentrate mix as optimal level.

A comparative study conducted by Getahun [15] using Blackhead Ogaden (BHO) and Afar sheep supplemented with increased concentrate levels (150, 300 , and $450 \mathrm{~g} / \mathrm{d}$ ) recorded weight gain in the range of 33 to $65 \mathrm{~g} /$ day and 37 to $79 \mathrm{~g} /$ day for BHO and Afar sheep, respectively with no significant difference between the two breeds. The effect of increasing levels of protein (20\% to $35 \%$ $\mathrm{CP}$ ) and energy (1.75 to $4 \mathrm{MJ} /$ day) supplements have also been investigated using BHO sheep [16]. In this study, ADG between 60 and $95 \mathrm{~g} /$ day were recorded. The figures are within the range of 30 to $116 \mathrm{~g} /$ day for BHO sheep supplemented with different levels of soybean meal to natural pasture hay [17]. Afar sheep fed Rhodes grass hay and supplemented with replacing commercial feed with Prosopis juliflora pods and leaves, attained daily body weight gain of 24 to $55 \mathrm{~g} / \mathrm{day}$ [18]. The use of graded levels of wheat bran as supplement with basal diet of urea treated teff straw supported growth rate of 64 to $88 \mathrm{~g} /$ day for Afar sheep [19].

A growth rate, $40 \mathrm{~g} / \mathrm{d}$ for Horro sheep supplemented with dried and ground Vernonia amygdalina leaves and ground sorghum grain mixture has been reported [20]. A similar growth rate of 24 to $47 \mathrm{~g}$ /day was reported for Adilo sheep supplemented with Enset (Ensete ventricosum), Atella and their mixtures at 300 g/day [21]. Higher value (117 g/day) than these have been reported for Horro 
Table 1. Response of Ethiopian sheep breeds to various levels and types of supplementation in terms of growth $(\mathrm{g} / \mathrm{d})$, slaughter body weight $(\mathrm{kg})$ hot carcass weight $(\mathrm{kg})$ and dressing percentage.

\begin{tabular}{|c|c|c|c|c|c|c|}
\hline \multirow[b]{2}{*}{ Breeds } & \multirow[b]{2}{*}{$\mathrm{ADG}$} & \multirow[b]{2}{*}{ SBW } & \multicolumn{4}{|c|}{ Dressing percentage } \\
\hline & & & $\mathrm{HCW}$ & SBW & EBW & Source \\
\hline Adilo & $24-48$ & $19-21$ & $7-8$ & $34-40$ & $48-53$ & {$[21]$} \\
\hline Afar & $37-79$ & $21-26$ & $9-12$ & $41-46$ & & [15] \\
\hline Afar & $65-88$ & $20-22$ & $8-10$ & $42-46$ & $52-56$ & [19] \\
\hline Afar & $49-67$ & $22-24$ & $9-11$ & & $51-55$ & [38] \\
\hline Afar & $24-56$ & $21-25$ & $7-11$ & $37-44$ & $48-55$ & [18] \\
\hline Afar & $34-77$ & $20-23$ & $9-10$ & $42-46$ & $52-55$ & [39] \\
\hline Arsi-Bale & $49-75$ & $23-25$ & $8-10$ & $35-38$ & $43-47$ & [40] \\
\hline Arsi-Bale & $62-87$ & $20-23$ & $9-11$ & $45-47$ & $54-56$ & [41] \\
\hline Arsi-Bale & $69-104$ & $21-24$ & $10-11$ & 46.0 & $53-56$ & [23] \\
\hline Arsi-Bale & $38-65$ & $22-24$ & $7.7-8.3$ & $32-37$ & $43-46$ & {$[42]$} \\
\hline Arsi-Bale & $55-88$ & $25-27$ & 12.0 & $40-44$ & $50-53$ & [24] \\
\hline $\mathrm{BHO}$ & $49-88$ & $18-22$ & $7-9$ & $40-43$ & $49-52$ & [43] \\
\hline $\mathrm{BHO}$ & $34-65$ & $18-24$ & $7-11$ & $36-44$ & & [15] \\
\hline $\mathrm{BHO}$ & $30-116$ & $16-24$ & $6-12$ & $37-49$ & $48-60$ & [17] \\
\hline $\mathrm{BHO}$ & $50-80$ & $19-22$ & $6.0-8.0$ & $31-37$ & $43-48$ & [36] \\
\hline $\mathrm{BHO}$ & $60-96$ & $24-26$ & $11-13$ & $43-48$ & $57-60$ & [16] \\
\hline $\mathrm{BHO}$ & $31-56$ & $16-17$ & $5-7$ & $32-41$ & $39-45$ & [35] \\
\hline Farta & $48-66$ & $22-23$ & $9-10$ & $42-44$ & $54-56$ & [25] \\
\hline Farta & $26-36$ & $18-20$ & $7-8$ & $38-38$ & $48-50$ & [26] \\
\hline Horro & $61-64$ & 25 & 12.0 & 44.0 & 53 & {$[44]$} \\
\hline Horro & 47 & 31 & 15.0 & 48.0 & & [29] \\
\hline Horro & $33-59$ & $21-24$ & $8-9$ & $35-36$ & $42-44$ & [32] \\
\hline Horro & $26-46$ & $20-22$ & $8-9$ & $39-40$ & $51-54$ & [33] \\
\hline Horro & 117 & 32 & 14 & 42 & 48 & {$[22]$} \\
\hline Horro & & 25 & 9.9 & 40 & & [30] \\
\hline $\mathrm{HH}$ & & $16-18$ & 8 & $38-43$ & & [45] \\
\hline $\mathrm{HH}$ & $50-60$ & $21-22$ & $7.7-8.2$ & $35-37$ & $42-44$ & [46] \\
\hline $\mathrm{HH}$ & $32-63$ & $20-22$ & $8-9$ & $38-41$ & & [27] \\
\hline $\mathrm{HH}$ & $63-78$ & $23-24$ & $9-10$ & $42-43$ & $51-52$ & [28] \\
\hline $\mathrm{HH}$ & 39.2 & 19.2 & 7 & 41.3 & 52.6 & [47] \\
\hline Menz & 45.5 & 28.9 & 14.2 & 49.1 & & [29] \\
\hline Menz & $1.9-68$ & $17-23$ & $5.8-9.7$ & $33.6-42.7$ & $44.3-52$ & {$[48]$} \\
\hline Menz & & 24.7 & 10.2 & 41.0 & & [30] \\
\hline Washera & $25-34$ & $21-23$ & $9.7-10.2$ & $46-48$ & $54-56$ & [49] \\
\hline Washera & $40-49$ & $22-24$ & $8-9$ & $34.8-35.2$ & $41-42$ & {$[32]$} \\
\hline Washera & $45-64$ & $29-31$ & $13-15$ & $45-47$ & $56-57$ & {$[50]$} \\
\hline Washera & $16-25$ & $18-19$ & $5.9-6.2$ & $33-34$ & 39 & [13] \\
\hline Washera & $88-126$ & $29-33$ & $14-18$ & $48-52$ & & [12] \\
\hline
\end{tabular}

BHO = Blackhead Ogaden, $\mathrm{HH}=$ Hararghe Highland, $\mathrm{ADG}=$ average daily gain, SBW = slaughter body weight, HCW = hot carcass weight, EBW = empty body weight. Note: The range values represent results obtained from low and high supplement level. 
sheep supplemented with 400 g/day concentrate (49.5\% noug cake, $49.5 \%$ ground maize grain and $1 \%$ salt) to Rhodes hay basal diet [22]. Arsi-Bale sheep supplemented with $300 \mathrm{~g} /$ day with linseed cake and/or wheat bran gained 69 $104 \mathrm{~g} /$ day [23]. Ermias et al. [24] also found ADG of 55 - $88 \mathrm{~g} /$ day for Arsi-Bale sheep fed faba bean haulms as a basal diet and supplemented with different proportions of barley bran and linseed meal.

In a study conducted by Aschalew and Getachew [25] the ADG observed in Farta sheep supplemented with different form of Lathyrus sativus was 47.8 to $65.6 \mathrm{~g} /$ day which is higher than 25 to $35 \mathrm{~g} /$ day gained when the same sheep breed was fed graded level of rape seed cake and rice bran mixture [26]. The growth rate of Hararghe Highland $(\mathrm{HH})$ sheep supplemented with concentrate mixtures to a basal diet of urea-treated maize stover ranges from 32 to $63 \mathrm{~g} /$ day [27]. This is lower than 62 to $77 \mathrm{~g} /$ day gain reported by Tagaynesh [28] for the same breed of sheep. For Menz sheep fed grass hay and supplemented with 400 g/d concentrate mix, ADG of $45 \mathrm{~g} /$ day has been recorded [29].

Generally past feeding trials (Table 1) reported a maximum ADG of 126 g/day for Washera sheep supplemented with 300 to $500 \mathrm{~g} /$ day Lathyrus sativus and maize grain to natural pasture grazing as a basal diet [12] and the growth rate increased as level of supplement increases up to its genetic limit. The variation in growth rate within the same sheep breed could be attributed to the low amount of the supplement in some of the studies which is insufficient to the animal to support its genetic potential for growth. This is due to differences in nutrient concentration and characteristics of the supplements used and partly because of the response of the sheep breed to various feed types.

Most of the indigenous Ethiopian sheep in various feeding system may not attain the final weight between 25 to $30 \mathrm{~kg}$ in one year required by live animal exporters. However, there is too much potential for indigenous sheep to attain this weight with better feeding and health care [12] [15] [16] [29] [30] (Table 1). However, despite sizeable information upon the response of sheep to various types of supplementary feeding, their full growth and other production traits for the majority of sheep breeds of the country are not well studied. Therefore, in future research work emphasis should be given to explore the genetic potential for various production traits of indigenous sheep breeds of the country.

\subsection{Carcass Production}

The carcass production potential of indigenous sheep in Ethiopia is between 7 to $18 \mathrm{~kg} /$ head (Table 1) and increased as supplement level increases. Hot carcass in the range between 6 to $17 \mathrm{~kg}$ has been reported for Washera breed (Table 1). The higher value (13 - $17 \mathrm{~kg}$ ) of hot carcass weight (HCW) was reported by Tesfaye et al. [12] when grazing Washera sheep were supplemented with 300 to 700 g/day concentrate mix and attain final weight of 29 to $33 \mathrm{~kg}$. On the contrary, different forms of white lupin (local variety) supplement to Rhodes grass hay basal diet to Washera sheep resulted in $6 \mathrm{~kg} \mathrm{HCW} \mathrm{[13].} \mathrm{A} \mathrm{wide} \mathrm{variation} \mathrm{among}$ 
studies (Table 1) in HCW and SBW implies that the supplement is insufficient to support the genetic potential for carcass production due to the quality and quantity of the supplement. Wilson [31] in his review indicated that feeding is one of the most important factors to influence meat production and carcass quality of small ruminants.

Horro sheep fed different types of supplement produced 8 to $9 \mathrm{~kg} \mathrm{HCW} \mathrm{[32]}$ [33]. The use of concentrate mixture $(50 \% \mathrm{WB}, 30 \%$ maize, $20 \%$ cotton seed cake) supplement with basal diet of natural pasture hay can yield about $15 \mathrm{~kg}$ HCW by Horro sheep [29]. In another study, HCW up to $18 \mathrm{~kg}$ has been recorded in various ages and under different feeding regimes for Horro sheep [34], which is among the highest HCW recorded for Ethiopian indigenous sheep.

The HCW recorded for BHO sheep fed urea molasses and urea Attela blocks is about 5 to $7 \mathrm{~kg}$ [35]. This is close to the average HCW of 6 to $8 \mathrm{~kg}$ [36] but lower than 10 to $12 \mathrm{~kg}$ [16] and 6 to $11 \mathrm{~kg}$ [17] reported for BHO sheep fed different types of feed. In the work of Facil et al. [37], higher HCW (13 kg) has been reported for one and half year BHO sheep fattened for three months following a growth experiment of 90 days. Generally from the feeding trials, the HCW reported so far for yearling BHO sheep fed various types of basal diets and supplements are in the range of 7 to $13 \mathrm{~kg}$ (Table 1 ). A HCW of 10 to $12 \mathrm{~kg}$ was reported for Afar sheep by different researchers when fed various types of basal and supplement feeds (Table 1).

The average HCW for supplemented Arsi-Bale sheep are between 8 and $12 \mathrm{~kg}$ (Table 1). Carcass production potential of Arsi-Bale sheep increased as concentrate supplement level increases. Arsi-Bale sheep supplemented with 200 to 400 g/day concentrate mix to urea treated barley straw basal diet had produced HCW between 8 to $10 \mathrm{~kg}$ [40]. Hararghe Highland (HH) sheep fed grass hay and supplemented with sole wheat bran or its mixture with safflower seed cake had HCW of 9 to $10 \mathrm{~kg}$ [28]. The use of Ficus sur fruits and oat grain as supplement for HH produced HCW of 6 to $8 \mathrm{~kg}$ [45]. Similarly, urea treated wheat straw as basal diet supplemented with Ensete ventricosum, Atella and their mixture fed to Adilo sheep result in 6 - $8 \mathrm{~kg} \mathrm{HCW} \mathrm{[41].}$

Generally, the past studies confirmed that at yearling age most of the indigenous Ethiopian sheep consumed various types of supplement feed produced carcass weight of $8-12 \mathrm{~kg}$ required by the export abattoirs to Middle East countries. However, there is potential for indigenous sheep to attain higher weight of carcass with better feeding [12] [34]. Moderate to high heritability estimates for slaughter $(0.46 \pm 0.15)$ and carcass weight $(0.48 \pm 0.15$ [30] coupled with the traits increase with increasing level of supplement (Table 1) suggests that, improvement could be possible through selection and improved feeding.

\subsection{Dressing Percentage}

Dressing percentage (DP) is an important measure of the potential yield of meat from an animal. According to the review by Ruvuna et al. [51], dressing percent 
is known to be affected by breed, age, castration and it is also highly affected by feeding and degree of fattening. Ewnetu et al. [30] studied the effect of breed on some carcass and non-carcass components of Horro and Menz sheep of Ethiopia. According to the authors, the two breeds had similar slaughter and carcass weights but have significantly different DP as slaughter body weight basis, which were $40 \%$ for Horro and $41 \%$ for Menz (Table 1 ), and the difference was ascribed to the higher gut fill in Horro sheep. The two breeds also significantly differ in edible non-carcass components, which were $4.3 \mathrm{~kg}$ for Menz and $4.6 \mathrm{~kg}$ for Horro sheep. These estimates represent about $21 \%$ and $23 \%$ of empty body weight in the Menz and Horro breeds, respectively. In another study, DP (SBW basis) of $49 \%$ and $48 \%$ has been recorded for Menz and Horro sheep, respectively in a trial compared the two breeds [29]. But, the result of the study did not show significant breed difference for DP since the higher SBW is offset by higher gut content in Horro sheep.

A comparative study was conducted to evaluate the effect of concentrate level and breed on carcass characteristics using BHO, Hararghe Highland ( $\mathrm{HH}$ ), and their F1crosses with Dorper sheep [47]. The study demonstrated significant breed and dietary level effect on most of the carcass parameters in general and in SBW, HCW, and DP in particular. However, significant difference was not observed between $\mathrm{HH}$ and $\mathrm{BHO}$ sheep. According to the study, DP in the range of $41 \%$ to $46 \%$ and $52 \%$ to $58 \%$ SBW and EBW, respectively were recorded.

As indicated in Table 1, the DP estimated for Ethiopia sheep ranged between $34 \%$ and $49 \%$ and $44 \%$ and $60 \%$ SBW and EBW basis, respectively. The values, $41 \%$ to $46 \%$ recorded for Ovin Martinik tropical hair sheep [52], $42 \%$ to $50 \%$ documented for ten Iranian native fat-tailed sheep breed [53], and $42.7 \%$ to 44.7\% SBW basis recorded for Tanzanian long fat-tailed castrate sheep [54] and $56.5 \%$ to $61.0 \%$ as EBW basis reported for West African dwarf sheep [55] are within the range reported for the Ethiopian sheep.

\subsection{Carcass Quality}

The carcass quality of Ethiopian indigenous sheep has not been well studied in the past. Most of the studies were focused on increasing carcass quantity except few research works conducted on Horro and Menz breeds [29] [30] and on $\mathrm{BHO}, \mathrm{HH}$ and their F1crosses with Dorper sheep [56]. On the other hand, meat production is shifting from a focus on quantity to quality in response to consumer demands [57]. Therefore the existing serious lack of information with regard to meat quality traits in Ethiopian indigenous sheep should be addressed in future research works.

It is well established that the main parameters of carcass quality are lean and fat proportions, lean: bone ratio and saleable meat yield because of their effect on the commercial value of sheep carcasses [58]. For these traits, significant variation is reported to exist among the two indigenous sheep breeds of Ethiopia [30]. According to the author, Menz sheep have significantly higher carcass fat 
( $8.7 \%$ vs $5.9 \%)$, lean: bone ratio $(2.7 \%$ vs $2.4 \%)$ but lower total saleable meat yield (carcass + edible non carcass component) than Horro sheep. This difference is attributed to breed effect as described by Ewnetu et al. [30]. With regard to chemical composition of carcass, Diriba et al. [45] reported chemical fat $4 \%$ to $7 \%$, CP $19 \%$ to $21 \%$ and moisture $69 \%$ to $72 \%$ from longissimus dorsi muscle of $\mathrm{HH}$ sheep, which are within the range estimated for other sheep breeds found elsewhere [45].

Along with breed effect, the effect of nutrition on carcass composition and conformation in indigenous sheep of Ethiopia and their F1 crosses with Dorper sheep has been documented [56]. According to the study, leaner carcass $(83.6 \%$ vs $51.4 \%$ ), lean: bone ratio (3.5 vs 2.6), and lean: fat ratio (7.6 vs 5.2 ) were registered from lambs consumed $150 \mathrm{~g} /$ day of concentrate supplement as compared to those lambs consumed $350 \mathrm{~g} /$ day. With regard to total bone and fat percentage, the differences between the dietary levels were not apparent. Among breeds evaluated, Dorper $\times \mathrm{HH}$ had significantly higher percent lean carcass $(74.9 \%$ vs $61.5 \%)$ and lean: fat ratio (7.8 vs 4.7$)$ than $\mathrm{BHO}$ sheep but pure $\mathrm{HH}$ breed and Dorper $\times$ BHO sheep had similar values. The result also revealed that, carcass with attractive conformation was obtained at $350 \mathrm{~g} /$ day of concentrate supplement as well as on Dorper $\times \mathrm{HH}$ and $\mathrm{BHO}$ breeds.

\subsection{Skin and Leather Quality Characteristics}

Ethiopian hair sheep skin traditionally has a very good reputation for quality in the world leather market due to their fine grain and compact nature. It is among the main commodities used to earn foreign currency in the country [59]. Research results showed that breed, nutrition, age and sex affect chemical and physico-mechanical quality of skin [60] [61] [62]. However, there is limited empirical information on the physical and chemical quality of skins or leathers produced from different indigenous sheep breeds of Ethiopia.

The study by Tsegay et al. [56] evaluated the effect of breed and concentrate level on physico-mechanical and chemical skin quality of $\mathrm{BHO}, \mathrm{HH}$ and their $\mathrm{F} 1$ crosses with Dorper sheep supplemented with two dietary concentrate levels (150 and $350 \mathrm{~g} /$ day/head) to a basal diet of natural pasture hay. According to the study, except skin thickness (only significant for diet), all other physico-mechanical skin/leather quality traits such as tensile strength and percentage elongation, tear strength, and grain strength were not significantly affected $(P>0.05)$ by level of supplementation and breeds. Similarly, chemical qualities of leather such as fat and chrome-oxide contents were not affected by both factors. In this study, although level of supplementation and breeds didn't show significant difference on the physico-mechanical skin quality, better qualities were obtained at 350 $\mathrm{g} /$ day/head of concentrate supplementation. On the other hand, numerically better chrome-oxide content was recorded at $150 \mathrm{~g} /$ day of supplement than 350 g/day due to low fat content of leather as the two are inversely related. Among the breeds, the leather obtained from $\mathrm{BHO}$ and $\mathrm{HH}$ had relatively good tensile 
strength, thickness, grain strength, and extensibility than their crosses. Snyman and Jackson-Moss [63] reported that lamb's genotype affected physico mechanical skin quality in comparative study of ten South African sheep breeds. Ebrahiem et al. [64] in Sudan also observed significant breed effect on the chemical and physico-mechanical skin quality. The effect of different roughage to concentrate ratio and amounts of supplement has also been investigated using $\mathrm{BHO}$ sheep [37]. In this study, diet has significant effect on skin thickness, moisture content (low), tear strength, tensile strength, percentage elongation, and grain strength in favor of high supplement but the difference was not apparent on fat and chrome-oxide contents.

\section{Level of Reproduction in Indigenous Ethiopian Sheep}

\subsection{Age at First Lambing}

Age at first lambing (AFL) is an important reproduction trait as greater population turnover and more rapid genetic progress can be obtained when sheep produce their first offspring at an earlier rather than later age. Early maturing females are known to have a relatively long and fruitful reproductive life.

Data on average AFL for most of the indigenous sheep in Ethiopia are between 11 and 16 months (Table 2) and most sheep breeds tend to have their first offspring before they are two years old. The AFL values found in most of Ethiopian sheep are within the range of 11.2 to 22.8 months reported for sub-Sahara

Table 2. Age at First Lambing and Lambing Intervals (Month) of Ethiopian Indigenous Sheep Breeds.

\begin{tabular}{ccccc}
\hline Breeds & AFL & LI & Management & Source \\
\hline Adilo & $11.8-14.6$ & & on farm & {$[76]$} \\
Adilo & 12.4 & 7.3 & on farm & {$[75]$} \\
Afar & 13.5 & 9.01 & on farm & {$[73]$} \\
Arsi-Bale & 12.7 & 7.8 & on farm & {$[72]$} \\
Arsi-Bale & 12.4 & 9.1 & on farm & {$[77]$} \\
BHO & 23.6 & 10.5 & on farm & {$[78]$} \\
BHO & 14.9 & 11.2 & on farm & {$[79]$} \\
Bonga & 13.67 & 6.6 & on farm & {$[6]$} \\
Gumz & 13.3 & & on farm & {$[71]$} \\
Horro & $10-11$ & $9-10$ & on farm & {$[6]$} \\
Horro & 13.5 & 8.7 & on farm & {$[80]$} \\
Horro & 15.7 & 8.5 & on farm & {$[74]$} \\
Menz & 16.5 & & on farm & {$[73]$} \\
Menz & 15.5 & 9.03 & on station & {$[70]$} \\
Washera & & on farm & {$[69]$} \\
\hline
\end{tabular}

$\mathrm{AFL}=$ age at first lambing; $\mathrm{LI}=$ lambing interval, $\mathrm{BHO}=$ Blackhead Ogaden; on farm= under farmers management, on station $=$ in research station (relatively under good management). 
African sheep breeds [65] but slightly lower than 18.8 to 22.6 month documented for West African Dwarf, Djallonke, sheep [66]. The AFL (10 - 11 month, Table 2) reported for $\mathrm{BHO}$ sheep is longer than the values documented for most of the indigenous sheep in Ethiopia. This is consistent with 24.4 month reported for Balochi sheep in different ecological zones of Balochistan, Pakistan [67] and appears to be due to the seasonal scarcity of feed resources.

Among the most important parameters affecting AFL, genotype and various management components [65] are the main one. Management, with regard to whether breeding is controlled or uncontrolled also tends to affect the age at first parturition [68]. The author observed delayed first parturitions in sheep that were bred in controlled breeding systems compared with sheep reared under uncontrolled systems, where rams are free to run with females and serve them at the earliest possible display of oestrus. Poor nutrition and disease can leads to delayed age at first lambing through limiting early animal growth. Year and season of birth in which the ewe lamb was born influence age at first lambing through their effect on feed supply and quality.

The results from previous studies generally show that AFL of Ethiopian sheep seems to have wide variation within and among breeds. This implicates the presence of huge opportunity to improve this trait through improved management and selection.

\subsection{Lambing Interval}

Lambing interval (LI) is defined as, the number of days between two consecutive parturitions. Results from the past research showed that, the LI for most Ethiopian indigenous sheep under traditional management are between 7 and 10 months (Table 2). These differences might be due to variation in breed, season, sex of lamb, type of birth (single, twin), parity [39] [66] [69], and post-partum body weight and management practice [70]. The LI documented for Ethiopian sheep is within the range of 7 to 12 months reported for sub -Saharan African sheep [65]. A study conducted by Abegaz et al. [71] has indicated the possibility of indigenous Ethiopian sheep to have more than three lambing in two years time. Similarly, [72] [73] [74] and Fsahatsion et al. [75] reported 7 - 9 months of LI for some indigenous sheep breeds in Ethiopia. Similar to Ethiopian sheep, three lambing in two years time are reported for West African Dwarf, Djallonke, sheep [66] and Balochi sheep in Pakistan [67].

Generally from the previous research result it can be concluded that through the provision of adequate diet and proper flock management, it is practically possible to attain three lambing in two years in most Ethiopian indigenous sheep.

\subsection{Litter Size}

Litter size (LS) or prolificacy is defined as the number of progenies born per parturition [65]. It is one of the most important reproductive parameters affect- 
ing the productivity of a dam and thereby the profitability of a farm. Litter size is a trait that depends on ovulation rate and is affected by the number of fertilized oocytes. The higher the ovulation rate, the more oocytes will be available for fertilization during the estrous and increase the possibility of bigger litters [81].

The main factors influencing ovulation rate in the ewes are breed and level of nutrition while season and age related factors are also important. Ovulation rates vary within and among breeds [82], increase with ewe age up to 6 - 7 years [83]. It is also affected to a large extent by ewe body weight at mating which itself is linked to nutrition. Poor nutrition during service period leads to reduced ovulation rates and increase embryonic mortality and consequently decrease litter size [70]. Ibrahim [84] reported that litter size can be increased $10 \%$ to $40 \%$ by improving the nutrition management of the pre-mating ewe or by treatment with gonadotropins. According to Abegaz et al. [85], with respect to weight of ewes at mating, litter size increased by $2.5 \%$ for each kilogram increase in weight at mating in Horro sheep. Litter size increased with age to about four years of age and remained somewhat similar thereafter [84].

The least squares mean of litter size reported by various workers for different indigenous sheep breeds of Ethiopia are presented in Table 3. It varied from 1.01 in BHO [79] to 1.7 in Arsi-Bale breed [72]. The LS reported for Afar, BHO, and to some extent for Menz sheep are smaller than the values documented for most of the indigenous sheep in Ethiopia. This is consistent with the results of other studies [86] and appears to be one mechanism of adaptation to the harsh environmental conditions and to the seasonal scarcity of feed resources. Most estimates of litter size in tropical sheep range from 1.0 to 1.5 indicating that twinning rate is generally between $0 \%$ and 50\% [84]. This trait in West African sheep breed was estimated at $1.24 \pm 0.33$ lambs [87], $1.149 \pm 0.031$ lambs in Afshari sheep breed [39]. Also litter size in sub-Saharan African sheep was 1.01 to 1.487 [65] with Arab sheep in the semi-arid zone of Chad showing the lowest values.

Generally from previous studies, it can be concluded that most Ethiopian sheep breeds have an ability to provide twining birth under traditional management system. Thus, there is huge opportunity to improve this trait through selection and improved management.

\subsection{Early Body Weight and Growth Rates}

Lambs with higher birth weights (BW) are expected to grow faster in life. BW is strongly influenced by breed [2] [88] [89] [90]. It is also affected by sex of lamb, birth type, age of dam, feeding level, season of birth and production system.

Data on average BW for indigenous sheep breed in Ethiopia are summarized in Table 4. The reported BW of Ethiopian indigenous sheep breed in traditional and in improved management are between 2 and $2.9 \mathrm{~kg}$. The BW (2.01 to $2.4 \mathrm{~kg}$ for Menz and 2.4 to $2.9 \mathrm{~kg}$ for Horro sheep) reported in improved management showed wide variation among studies. These difference could be arise mainly 
Table 3. Litter size of indigenous sheep breeds of Ethiopia.

\begin{tabular}{|c|c|c|c|}
\hline Breeds & LS & Management & Source \\
\hline Adilo & 1.42 & on farm & {$[76]$} \\
\hline Adilo & 1.3 & on farm & {$[75]$} \\
\hline Afar & 5.49 (\% twining rate) & on farm & {$[73]$} \\
\hline Afar & 1.05 & & {$[84]$} \\
\hline Arsi-Bale & 1.7 & on farm & {$[72]$} \\
\hline Arsi-Bale & 1.52 & on farm & [77] \\
\hline BHO & 1.04 & on station & [4] \\
\hline BHO & 1.01 & on farm & [79] \\
\hline Bonga & 1.36 & on farm & [6] \\
\hline Bonga & 1.4 & on farm & {$[96]$} \\
\hline Gumz & 1.17 & on farm & [71] \\
\hline Horro & 1.4 & on farm & {$[6]$} \\
\hline Horro & 1.34 & on station & [97] \\
\hline Horro & 1.21 & on farm & {$[74]$} \\
\hline Horro & 1.34 & on station & {$[85]$} \\
\hline Menz & 1.02 & on farm & [98] \\
\hline Menz & 1.14 & on farm & [99] \\
\hline Menz & 1.03 & on farm & {$[100]$} \\
\hline Menz & 1.11 & on farm & [101] \\
\hline Washera & 1.1 & on farm & [69] \\
\hline
\end{tabular}

LS = litter size, $\mathrm{BHO}=$ Blackhead Ogaden; on farm $=$ under farmers management, on station $=$ in research station (relatively under good management).

Table 4. Birth weight, Weaning weight, pre-weaning growth rate and pre-weaning mortality rate of indigenous sheep breeds of Ethiopia.

\begin{tabular}{cccccc}
\hline Breeds & BW $(\mathrm{kg})$ & WW $(\mathrm{kg})$ & PWGR $(\mathrm{g} /$ day $)$ & PWMR & Source \\
\hline Adilo & $2.29-2.89$ & $11.1-12.23$ & & 19.8 & {$[76]$} \\
Afar & 2.36 & 8.5 & 67.78 & & {$[90]$} \\
Afar & 2.7 & 11.5 & & & {$[103]$} \\
Arsi-Bale & 2.3 & 10.35 & 89.24 & 13.9 & {$[77]$} \\
Arsi-Bale & 2.8 & 13.5 & - & & {$[104]$} \\
BHO & & & & 47.8 & {$[78]$} \\
BHO & 2.7 & & 127.8 & & {$[4]$} \\
BHO & & 7.9 & 58.2 & 18.3 & {$[79]$} \\
Bonga & & 11.6 & & 56.9 & {$[6]$} \\
Bonga & 2.89 & 12.5 & & 51.25 & {$[71]$} \\
Gumz & 2.79 & & & \\
\hline
\end{tabular}




\section{Continued}

\begin{tabular}{cccccc}
\hline Horro & 2.4 & 9.48 & 78 & 33 & {$[2]$} \\
Horro & 2.43 & 8.21 & 68.1 & 24.3 & {$[29]$} \\
Horro & 2.4 & 9.4 & 67 & 25.3 & {$[88]$} \\
Horro & 2.6 & 12.2 & 100 & & {$[105]$} \\
Menz & 2.17 & 8.03 & 69.4 & 10.6 & {$[29]$} \\
Menz & 2.06 & 8.64 & 72.6 & 19.2 & {$[2]$} \\
Menz & 2.5 & 9.5 & 78 & & {$[106]$} \\
Menz & 2.1 & 8.4 & 61 & 8.8 & {$[88]$} \\
Menz & 2.4 & 8.3 & & 39.5 & {$[98]$} \\
Simien & 2.97 & 11.8 & 97.4 & & {$[107]$} \\
Sekota & 2.7 & 11.9 & 102 & & {$[108]$} \\
Washera & 2.7 & 11.9 & 103.7 & - & {$[69]$} \\
\hline
\end{tabular}

$\mathrm{BW}=$ birth weight, $\mathrm{WW}=\mathrm{Weaning}$ weight, $\mathrm{PWMR}=$ pre-weaning growth rate; $\mathrm{PWMR}=$ pre-weaning mortality rate; $\mathrm{BHO}=$ Blackhead Ogaden; on farm = under farmers management, on station = in research station (relatively under good management).

due to varying climatic conditions (amount of annual rainfall) in years affecting the availability of pastures to the ewes carrying lambs as well as variation in supplementary feed offer. The differences in birth weight among lambs born with the same breed were attributed to differences in selection of rams and ewes [91]. The agro-climatic condition in which the experiment station is located could also be one source of variation. This is partly consistent with the results of other studies [92] who obtained 2.24 to $2.36 \mathrm{~kg}, 1.92$ to $2.22 \mathrm{~kg}$ and 1.98 to $2.15 \mathrm{~kg}$ for Barri, Black Boni, and Whit Boni sheep breeds' of Yemeni, respectively within the year 1992 to 2009.

The weaning weight (WW) or weight at the age of three month and pre-weaning growth rate (PWGR) of indigenous Ethiopian sheep breeds reported by various researchers are presented in Table 4. It varied from 8 to $12 \mathrm{~kg}$ and 58.2 to 134.4 $\mathrm{g} / \mathrm{d}$ for WW and PWGR, respectively. The reason for variation in WW and PWGR among genotypes in the previous studies was partly because of difference in growth potential among breeds [3] [89] [90] [93]. It can also be due to differences in birth weight. Yilmaz [94] has reported a positive correlation between birth weight and subsequent live body weight development in sheep. Similarly, in the work of Tibbo [3] and Lakew et al. [90] indicated that lambs heavier at birth grow faster than light weight lambs.

Weaning weight and ADG are also known to be affected by the mothering ability of the dam [29]. This is because there is more dependency on the milk production of the ewe as the lamb meets most of its requirement through suckling rather than on forage at the early growth phase. The environment under which the animals are maintained including the availability of adequate feed supply in terms of both quantity and quality are also one source of variation [95]. The average WW (Table 4) tend to be closer in the ranges of 9.28 to 12.47 
reported for Barri Black Boni and White Boni breeds of Yemeni [92].

\subsection{Pre-Weaning Mortality}

Pre-weaning mortality rate (PWMR) refers to death occurring between births and weaning of lambs born alive including neonatal deaths [65]. The average PWMR of most Ethiopian indigenous sheep vary from $8 \%$ to $60 \%$ (Table 4), which is closer to $10 \%$ to $44 \%$ variation reported for sub-Saharan African sheep [65] and $12 \%$ to $50 \%$ range for tropical sheep [102]. The previous studies generally indicated that mortality is major constraint to improve productivity of sheep in Ethiopia.

Studies indicated that PWMR in the lambs is influenced by genotype, birth weight, litter size, and season while sex and parity are also important. Mukasa-Mugerwa et al. [88] working on indigenous Ethiopian Menz and Horro sheep reported significantly lower proportion of Menz lambs died before 1 year of age (28\%) than the Horro lambs (59\%) when the ewes were mated by single sir. Similarly, a study conducted in station on the same sheep breed show that, the survival rate between birth and weaning (90 days) for Menz lambs (89\%) was significantly higher than that for the Horro (76\%) [29].

Many studies indicated the negative relationship between birth weight and pre-weaning lamb mortality [2] [88]. Nowak and Poindron [109] identified curvilinear relationship between birth weight and most death of lambs. The chances of lamb survival tend to reduce considerably when the lamb is $2 \mathrm{~kg}$ or less [2] [110]. This is because lambs with low birth weights have lower energy reserves, lowered thermoregulatory capability, and therefore less able to withstand harsh environmental conditions. Mukasa-Mugerwa et al. [110] have recommended that lambs have to be born with birth weights of $2.0 \mathrm{~kg}$ or more to have a peri-natal survival rate of $90 \%$. Therefore, to ensure lamb survival strategic energy and protein supplementation to ewe during the gestation period and at the time of lambing should be given due attention to improve birth weight of the offspring as well as the milk production of the ewe. Generally, breeding and management practices should aim at heavier weight at birth.

Litter size and dam parity influence PWMR through their effect on lamb birth weight. Dam parity also affects PWMR through mothering ability (milk production). Lambs from multiple births are usually weak and of low weights at birth as a result of physiological starvation in the uterus and this situation is even more critical if dams are not producing enough milk [29]. Birth weight and milk production potential of a dam increase as parity increases. Research report indicated that lambs born by younger ewes have depressed birth weight due to relative competition for nutrients between the still growing ewes and developing foetus [91].

As indicated in Table 3 there is high possibility of getting twin birth in Ethiopian indigenous sheep. Therefore, local farmers should be encourage to adopt discriminate supplementary feeding of the ewes (the pregnant, the single, and 
twin bearing ewes) or the ewe should be selected against multiple birth if supplementary feeds are not in place to curb pre weaning mortality through high birth weight.

Various studies indicated that the presence of sex difference in lamb survival is in favor of female lambs [2]. Low survival in male lambs than in female could be associated partly with hormonal effect on the immune function. This was indicated by Schuurs and Verhuel [111] that castrated males had similar risk with females and lesser risk compared to non-castrated. Norwak [112] reported, in twin born lambs that, the dam recognition ability of female lambs was superior to their male counterparts after separation. Dwyer [113] found out that the male lambs were slower to stand and suck than the female lambs in suffolk sheep breed, but not in black face breed. Therefore some level of prenatal treatment in favor of male lambs may be necessary to improve prenatal survival.

Seasonal influence on lamb mortality has been well established through its effect on feed availability. This is because sheep in tropics in general and in Ethiopia in particular are primarily depend on natural pasture grazing and crop residue whose supply and quality fluctuates seasonally. In Ethiopia, feed is relatively better both in quality and quantity in the rainy season and the reverse happen in the dry season. Consequently, lambs born in the wet season had higher birth weight, pre-weaning average daily gain and high survival than their contemporaries born in the dry season [2]. Therefore adjusting the breeding season to feed availability could be one possible solution. However, in Ethiopia breeding is not seasonal and uncontrolled.

Generally, the degree to which lambs survive to a marketable age and/or to a sustainable reproductive life is one of the key indicators of the efficiency of a sheep production system. Therefore to ensure lambs survival, improving nutritional conditions of the pregnant ewes and newly born lambs coupled with disease and parasite control measures should be adopted by local farmers. The concerned body should provide necessary support for farmers to reduce pre-weaning mortality in indigenous sheep of Ethiopia.

\section{Conclusions and Recommendation}

Generally, the past studies confirmed that, at yearling age, most of the indigenous Ethiopian sheep consumed various types of supplement feed attain 18 - 26 $\mathrm{kg}$ live weight and produced carcass weight of $8-12 \mathrm{~kg}$. However, there is potential for indigenous sheep to attain higher weight of carcass with better feeding and health care. Therefore, in future emphasis should be given to explore the genetic potential for various production traits of indigenous sheep breeds of the country with improved feeding and healthcare.

The carcass quality of Ethiopian indigenous sheep has not been well studied in the past and most of the studies were focused on increasing the volume of the product. On the other hand, meat production is shifting from a focus on quantity to quality in response to consumer demands. Therefore the existing serious 
lack of information with regard to meat quality traits in Ethiopian indigenous sheep should be addressed in future research works.

Regarding the reproductive performance, results from the previous studies generally showed that AFL, LI, and litter size of Ethiopian sheep seems to have wide variation within and among breeds. This implicates the presence of huge opportunity to improve these traits through improved management and selection.

\section{Acknowledgements}

The work is partially part of PhD study for the first author and we are grateful to Haramaya University for funding this research.

\section{Conflicts of Interest}

The authors declare no conflicts of interest regarding the publication of this paper.

\section{References}

[1] CSA (Central Statistic Agency) (2017) Federal Democratic Republic of Ethiopia, Agricultural Sample Survey Report on Livestock and Livestock Characteristics. pp. 38. VOLUME II, Addis Ababa, Ethiopia.

[2] Gizaw, S., Van Arendonk, J.A.M., Komen, H., Windig, J.J. and Hanotte, O. (2007) Population Structure, Genetic Variation and Morphological Diversity in Indigenous Sheep of Ethiopia. Journal of Animal Genetics, 38, 621-628. https://doi.org/10.1111/j.1365-2052.2007.01659.x

[3] Tibbo, M. (2006) Productivity and Health of Indigenous Sheep Breeds and Crossbreds in the Central Ethiopian Highlands. PhD Dissertation, Swedish University, Uppsala.

[4] Galal, E.S.E. (1983) Sheep Germplasm in Ethiopia. Animal-Genetic-ResourcesInformation, 1, 4-12.

[5] Nigussie, H., Mekasha, Y., Kebede, K., Abegaz, S. and Kumar Pal, S. (2013) Production Objectives, Breeding Practices and Selection Criteria of Indigenous Sheep in Eastern Ethiopia. Livestock Research for Rural Development, 25, 157. http://www.lrrd.org/lrrd25/9/nigu25157.htm

[6] Zewdu, E., Aynalem, H., Markos T., Sharma, A. K., Dejene, A., Sölkner, J. and Maria, W. (2009) Morphological Characterization of Bonga and Horro Indigenous Sheep Breeds under Smallholder Conditions in Ethiopia. Ethiopian Journal Animal Production, 9, 117-136.

[7] Getachew, T., Haile, A., Tibbo, M., Sharma, A. K., Sölkner, J. and Wurzinger, M. (2010) Herd Management and Breeding Practices of Sheep Owners in a Mixed Crop-Livestock and a Pastoral System of Ethiopia. African Journal of Agricultural Research, 5, 685-691.

[8] Getachew, L. and Mohamadou, F. (2014) Small Ruminant Value Chain Development in Ethiopia: Situation Analysis and Trends. ICARDA/ILRI Project Report.

[9] Aschalew, T. (2006) Assessment of Feeding Systems And Evaluation Of Feed Supplementation On Body Weight and Fleece Production of Sheep In Ethiopia. PhD Dissertation, Kasetsart University, Bangkok. 
[10] Oddy, V.H. and Sainz, R.D. (2002) Nutrition for Sheep-Meat Production. In: Freer, M. and Dove, H., CSIRO Plant Industry Canberra Australia, Eds., Sheep Nutrition, CABI Publishing, CAB International Oxon OX10 8DE, UK, 237-263. https://doi.org/10.1079/9780851995953.0237

[11] Solaiman, S.G. (2010) Goat Science and Production. A John Wiley and Sons, Inc., Publication. Iowa State University Press, Ames, AI.

[12] Tesfaye, G., Solomon, G., Sisay, L. and Mengistie, T. (2011) Breeding Practices, Growth, And Carcass Potential of Fat-Tailed Washera Sheep Breed in Ethiopia. Tropical Animal Health Production, 43, 1443-1448. https://doi.org/10.1007/s11250-011-9874-5

[13] Gebru, T., Firew, T., Atsushi, T., Yeshambel, M. and Solomon, M. (2015) Effects of Different Forms of White Lupin (Lupinus albus) Grain Supplementation on Feed Intake, Digestibility, Growth Performance and Carcass Characteristics of Washera Sheep Fed Rhodes Grass (Chloris gayana) Hay-Based Diet. Tropical Animal Health Production, 47, 1581-1590. https://doi.org/10.1007/s11250-015-0901-9

[14] Likawent, Y., Claudia, K., Firew, T. and Kurt, J.P. (2012) Sweet Blue Lupin (Lupinus angustifolius L.) Seed as a Substitute for Concentrate Mix Supplement in the Diets of Yearling Washera Rams Fed on Natural Pasture Hay as Basal Diet in Ethiopia. Tropical Animal Health and Production, 44, 1255-1261. https://doi.org/10.1007/s11250-011-0066-0

[15] Getahun, K. (2014) Effect of Concentrate Supplementation on Performances of Ethiopian Lowland Afar and Blackhead Ogaden Lambs. Journal of Animal and Veterinary Sciences, 2, 36-41. https://doi.org/10.11648/j.avs.20140202.14

[16] Wogenie, B. (2007) Effects of Increasing Levels of Energy and Protein Supplementation on Feed Intake, Body Weight Change and Carcass Composition of Blackhead Somali Sheep Fed on Grass Hay. MSc Thesis, Haramaya University, Haramaya.

[17] Kiflay, W., Getachew, A. and Mengistu, U. (2014) Effect of Different Levels of Soybean/Glycine Max/Meal Supplementation on Feed Intake, Digestibility, Live Weight Changes, and Carcass Characteristics of Black Head Ogaden Sheep. East African Journal of Sciences, 8, 135-146.

[18] Ahmed, S., Sayan, T., Sarawut, R. and Kriengki, K. (2012) Effect of Feeding Prosopis julifl ora Pods and Leaves on Performance and Carcass Characteristics of Afar Sheep. Kasetsart Journal of Natural Science, 46, 871-881.

[19] Awet, E. and Solomon, M. (2009) Supplementation of Graded Levels of Wheat Bran to Intact and Castrated Afar Sheep Fed Urea Treated Tef Straw: Effects on Feed Intake, Digestibility, Body Weight and Carcass Characteristics. East African Journal of Sciences, 3, 29-36.

[20] Firisa, W., Adugna, T. and Diriba, D. (2013) Feed Intake, Digestibility and Growth of Horro Lambs Fed Natural Pasture Hay Supplemented with Graded Level of Vernonia amygdalina Leaves and Sorghum Grain Mixture. Star Journal Science Technology, 2, 30-37.

[21] Feleke, A., Mengistu, U. and Getachew, A. (2015) Weight Gain and Carcass Characteristics of Adilo Sheep Fed Urea Treated Wheat Straw Supplemented with Enset (Ensete ventricosum), Atella and Their Mixtures. Journal of Biology, Agriculture and Healthcare, 5.

[22] Chala, M., Ulfina, G., Tesfaw, A. and Lemma, F. (2014) Growth Performance and Carcass Characteristics of Horro Rams under Different Management Practices at Ambo University, Ethiopia. Global Journal of Animal Scientific Research, 2.

[23] Abebe, T., Solomon, M. and Kurt, J.P. (2010) Supplementation with Linseed (Linum 
usitatissimum) Cake and/or Wheat Bran on Feed Utilization and Carcass Characteristics of Arsi-Bale Sheep. Tropical Animal Health Production, 42, 677-685. https://doi.org/10.1007/s11250-009-9475-8

[24] Ermias, T., Solomon, M. and Mengistu, U. (2013) The Effect of Barley Bran, Linseed Meal and Their Mixes Supplementation on The Performances, Carcass Characteristics and Economic Return of Arsi-Bale Sheep. Small Ruminant Research, 114, 35-40. https://doi.org/10.1016/j.smallrumres.2013.05.010

[25] Aschalew, A. and Getachew, A. (2013) Supplementation of Raw, Malted and Heat Treated Grass Pea (Lathyrus sativus) Grain on Body Weight Gain and Carcass Characteristics of Farta Sheep. International Journal of Soil and Crop Sciences, 1, 1-6.

[26] Melese, D. (2011) Effect of Supplementation of Hay with Graded Level of Rapeseed Cake and Rice Bran Mixture on Feed Intake, Digestibility, Body Weight Change and Carcass Characteristics of Farta Sheep. MSc Thesis, Haramaya University, Haramaya.

[27] Hirut, Y., Solomon, M. and Mengistu, U. (2011) Effect of Concentrate Supplementation on Live Weight Change and Carcass Characteristics of Hararghe Highland Sheep Fed a Basal Diet of Urea-Treated Maize Stover. Livestock Research for Rural Development, 23. http://www.lrrd.org/lrrd23/12/hiru23245.htm

[28] Tagaynesh, A. (2014) Supplementation of Sole Wheat Bran or Its Mixture with Safflower Seed Cake on Performance of Hararghe Highland Sheep Fed Grass Hay Basal Diet. Msc Thesis, Haramaya University, Haramaya.

[29] Kassahun, A. (2000) Comparative Performance Evaluation of Horro and Menz Sheep of Ethiopia under Grazing and Intensive Feeding Conditions. Doctoral Dissertation, Humboldt University, Berlin.

[30] Ewnetu, E., Alemu, Y. and Rege, J.E.O. (2006) Slaughter Characteristics of Menz and Horro Sheep. Small Ruminant Research, 64, 10-15. https://doi.org/10.1016/j.smallrumres.2005.03.007

[31] Wilson, R.T. (1992) Goat Meat Production and Research in Africa and Latin America. Pre-Conference Proceedings of the 5 th International Conference on Goats, New Delhi, March 1992, Vol. 2, 458-772.

[32] Assefu, G. (2012) Comparative Feedlot Performance of Washera and Horro Sheep Fed Different Roughage to Concentrate Ratio. Msc Thesis, Haramaya University, Haramaya.

[33] Dereje, K. (2012) Evaluation of Multi-Nutrient Blocks and Activated Effective Microorganisms on Intake, Digestibility, Body Weight Changes and Carcass Parameters of Intact Horro Rams Fed Rhodes Grass Hay. MSc Thesis, Haramaya University, Haramaya.

[34] Solomon, G. and Solomon, A. (1995) Changes in Carcass Characterization of Horro Rams with Increasing Age and Body Weight under Different Feeding Regimes. Proceeding of the 3rd Annual Conference of Ethiopian Society of Animal Production, Addis Ababa, 21-29 April 1995, 233-239.

[35] Geaush, F. (2011) Comparison of Supplementing Urea Molasses and Urea Attela Blocks on Feed Intake, Digestibility, Body Weight Change and Carcass Characteristics of Male Black Head Ogaden Sheep Fed Natural Pasture Hay. MSc Thesis, Haramaya University, Haramaya.

[36] Yohannes, U., Getachew, A. and Mohammed, Y. (2015) Supplementation of Different Level of Corn Silage with Linseed Meal on Performance of Blackhead Ogaden Sheep Fed Grass Hay. Science Technology Arts Research Journal, 4, 101-110. 
[37] Fasil, N., Mengistu, U., Yoseph, M. and Getachew, A. (2015) Effects of Different Feeding Regimes on Leather Quality of Finished Blackhead Ogaden Sheep. Science, Technology and Arts research Journal, 4, 222-227.

[38] Tesfay, H. and Solomon, M. (2009) Feed Intake, Digestibility, Body Weight and Carcass Parameters of Afar Rams Fed Teff (Eragrostis teff) Straw Supplemented with Graded Levels of Concentrate Mix. Tropical Animal Health Production, 41, 599-606. https://doi.org/10.1007/s11250-008-9230-6

[39] Mohammadi, A.R., Abbasi, M.A., Moghaddam, A.A. and Zare Shahneh, A. (2011) Determination of Some Reproductive Traits in Iranian Afshari Sheep Breed. Australian Journal of Basic and Applied Sciences, 5, 2742-2751.

[40] Abebe, G. and Yoseph, M. (2015) Effect of Supplementation with on Feed Intake, Digestibility, Body Weight Change, Carcass Parameters and Economic Benefit of Arsi-Bale Sheep Fed With Basal Diet of Urea Treated Barley Straw. Science, Technology and Arts Research Journal, 4, 1-8.

[41] Girma, H., Getachew, A. and Mengistu, U. (2014) Effect of Different Proportion of Malted Oat Grain and Noug Seed Cake Supplementation on Digestibility and Performance of Arsi-Bale Sheep Fed Grass Hay Basal Diet. International Journal Applied Science Engineering, 2, 28-36.

[42] Teklu, W. (2016) Effects of Feeding Different Varieties of Faba Bea (Vicia faba L.) Straws with Concentrate on Feed Intake Digestibility, Body Weight Gain and Carcass Characteristics of Arsi-Bale Sheep. Msc Thesis, Haramaya University, Haramaya.

[43] Birhanu, T., Getachew, A. and Mengistu, U. (2013) Effect of Green Prosopis juliflora Pods and Noug Seed (Guizotia abissynica) Cake Supplementation on Digestibility and Performance of Black Head Ogaden Sheep Fed Hay as a Basal Diet. Science, Technology and Arts Research Journal, 2, 38-47. https://doi.org/10.4314/star.v2i2.98881

[44] Bahran, F. (2014) Effect of Cassava Leaf Meal Substitution on Feed Intake, Digestibility, Body Weight Gain and Carcass Parameters in Horro Yearling Sheep. MSc Thesis, Haramaya University, Haramaya.

[45] Diriba, D., Yoseph, M., Mengistu, U. and Adugna, T. (2015) Carcass Yield and Composition of Supplementing Hararghe Highland Sheep with Ficus sur (cv. Forssk.) Fruits to a Basal Diet of Natural Pasture Hay. Science, Technology and Arts Research Journal, 4, 9-17. https://doi.org/10.4314/star.v4i4.2

[46] Merhun, L., Mengistu, U. and Yoseph, M. (2016) Effects of Supplementation with Different Levels of Wheat Bran and Noug Seed (Guizotia abissynica) Cake Mixtures on Performance of Hararghe Highland Sheep Fed a Basal Diet of Maize Stover. American Journal of Agricultural Science, 3, 40-47.

[47] Tsegay, T., Yoseph, M. and Mengistu, U. (2013) Comparative Evaluation of Growth and Carcass Traits of Indigenous and Crossbred (Dorper $\times$ Indigenous) Ethiopian Sheep. Small Ruminant Research, 114, 247-252.

https://doi.org/10.1016/j.smallrumres.2013.07.003

[48] Gezu, T. (2011) Effects of Supplementation with Graded Levels of Concentrate Mix of Oats Grain and Lentil Screening on the Performance of Menz Sheep Fed Hay. MSc Thesis, Haramaya University, Haramaya.

[49] Hailu, A., Solomon, M., Berhan, T. and Asaminew, T. (2011) Body Weight and Carcass Characteristics of Washera Sheep Fed Urea Treated Rice Straw Supplemented with Graded Levels of Concentrate Mix. Livestock Research for Rural Development, 23. http://www.lrrd.org/lrrd23/8/hail23164.htm 
[50] Mesganaw, A. (2014) Effect of Different Proportions of Field Pea (Pisum sativum L.) Hull and Concentrate Mixture Supplementation on Feed Intake, Digestibility, Body Weight Change and Carcass Parameters of Washera Sheep Fed a Basal Diet of Grass Hay. MSc Thesis, Haramaya University, Haramaya.

[51] Ruvuna, F., Taylor, J.F., Okeyo, M., Wanyoike, M. and Ahuya, C. (1992) Effects of Breed and Castration on Slaughter Weight and Carcass Composition of Goats. Small Ruminant Research, 7, 175-183. https://doi.org/10.1016/0921-4488(92)90206-J

[52] Archimede, H., Pellonde, P., Despois, P., Etienne, T. and Alexandre, G. (2008) Growth Performances and Carcass Traits of Ovin Martinik Lambs Fed Various Ratios of Tropical Forage to Concentrate under Intensive Conditions. Small Ruminant Research, 75, 162-170. https://doi.org/10.1016/j.smallrumres.2007.10.001

[53] Kiyanzad, M.R. (2005) Comparison of Carcass Composition of Iranian Fat-Tailed Sheep. Asian-Australian Journal of Animal Science, 18, 1348-1352. https://doi.org/10.5713/ajas.2005.1348

[54] Shirima, E.J.M., Mtenga, L.A., Kimambo, A.E., Laswai, G.H, Mgheni, D.M., Mushi, D.E., Shija, D.S. and Safari, J.G. (2014) Influence of Age at Entry and Level of Concentrate Feeding on Growth and Carcass Characteristics of Feedlot-Finished Tanzanian Long-Fat-Tailed Sheep. Tropical Animal Health Production, 46, 815-822. https://doi.org/10.1007/s11250-014-0570-0

[55] Fasae, O.A., Adu, I.F., Aina, A.B.J. and Dipeolu, M.A. (2011) Growth Performance, Carcass Characteristics and Meat Sensory Evaluation of West African Dwarf Sheep Fed Varying Levels of Maize and Cassava Hay. Tropical Animal Health Production, 43, 503-510. https://doi.org/10.1007/s11250-010-9723-y

[56] Tsegay, T., Mengistu, U. and Yoseph, M. (2012) Carcass Measurement, Conformation and Composition of Indigenous and Crossbred (Dorper $\times$ Indigenous) F1 Sheep. Pakistan Journal of Nutrition, 11, 1055-1060.

https://doi.org/10.3923/pjn.2012.1055.1060

[57] Sosnicki, A.A. and Newman, S. (2010) The Support of Meat Value Chains by Genetic Technologies. Meat Science, 86, 129-137. https://doi.org/10.1016/j.meatsci.2010.04.034

[58] Taylor, S.C., Murray, J.I. and Thonney, M.L. (1989) Breed and Sex Differences among Equally Mature Sheep and Goat. Animal Production Science, 49, 385-340. https://doi.org/10.1017/S0003356100032608

[59] ILRI (International Livestock Research Institute) (2013) Study of the Ethiopian Live Cattle and Beef Value Chain. ILRI Discussion Paper 23, Addis Ababa, 48 p.

[60] Stosic, P. (1994) Biological Factors Influencing the Nature of Goat Skins and Leather. MSc Thesis, Leicester University.

[61] Jacinto, M.A.C., Junior, F.M., deV, Martins, C.F., Pinto, G., dos, S., Reis, F.A. and de Oliveira, A.R. (2011) Influence of Genotype on the Quality of Sheep Leather. Revista Brasileira de Zootecnia, 40, 1830-1836. https://doi.org/10.1590/S1516-35982011000800029

[62] Salehi, M., Lavvaf, A. and Farahvash, T. (2013) Skin Quality and Physical Properties of Leather Based on Sex, Age and Body Parts of Goats Reared on Sub-Humid Hill Country. Iranian Journal of Applied Animal Science, 3, 853-857.

[63] Snyman, M.A. and Jackson-Moss, C.A. (2000) A Comparison of Leather Properties of Skins from Ten Different South African Sheep Breeds. South African Journal of Animal Science, 30, 129-130. https://doi.org/10.4314/sajas.v30i4.3941 
[64] Ebrahiem, M.A., Turki, I.Y. and Haroun, H.E. (2015) Effect of Breed Variation on Skin/Leather Quality of Sudan Desert Sheep. Global Journal of Animal Scientific Research, 3, 136-141.

[65] ILCA Working Document (1995) Reproductive Losses in Small Ruminants in Sub-Saharan Africa: A Review.

[66] Gbangboche, A.B., Adamou-Ndiaye, M., Youssao, A.K., Farnir, I.F., Detilleux, J., Abiola, F.A. and Leroy, P.L. (2006) Non-Genetic Factors Affecting the Reproduction Performance, Lamb Growth and Productivity Indices of Djallonke Sheep. Small Ruminant Research, 64, 133-142. https://doi.org/10.1016/j.smallrumres.2005.04.006

[67] Jahan, M., Tariq, M.M., Kakar, M.A. and Waheed, A. (2013) Reproductive Performance of Balochi Sheep in Different Ecological Zones of Balochistan, Pakistan. Pakistan Veterinary Journal, 33, 37-40.

[68] Wilson, R.T. (1989) Reproductive Performance of African Indigenous Small Ruminants under Various Management Systems: A Review. Animal Reproduction Science, 20, 265-286. https://doi.org/10.1016/0378-4320(89)90075-4

[69] Mengistie, T., Girma, A., Sisay, L. and Solomon, G. (2011) Reproductive Performance and Survival of Washera Sheep under Traditional Management System at Yilmanadensa and Quarit Districts of the Amhara National Regional State, Ethiopia. Journal of Animal and Veterinary Advances, 10, 1158-1165. https://doi.org/10.3923/javaa.2011.1158.1165

[70] Gautsch, K.D. (1987) Comparative Productivity of Indigenous Sheep in the Highland Areas of Ethiopia and Rwanda. SRCG Working Document No 14, ILCA, Addis Ababa.

[71] Abegaz, S., Hegde, B.P. and Taye, M. (2011) Growth and Physical Body Characteristics of Gumuz Sheep under Traditional Management Systems in Amhara Regional State, Ethiopia. Livestock Research for Rural Development, 23. http://www.lrrd.org/lrrd23/5/abeg23117.htm

[72] Tsedeke, K. (2007) Production and Marketing Systems of Sheep and Goats in Alaba, Southern Ethiopia. Msc Thesis, Hawassa University, Hawassa.

[73] Tesfaye, G. (2008) Characterization of Menz and Afar Indigenous Sheep Breeds of Smallholders and Pastoralists for Designing Community-Based Breeding Strategies in Ethiopia. M.Sc. Thesis, Haramaya University, Haramaya.

[74] Belay, B. and Haile, A. (2009) Reproductive Performance of Traditionally Managed Sheep in the South Western Part of Ethiopia. Livestock Research for Rural Development, 21. http://www.lrrd.org/lrrd21/9/bela21154.htm

[75] Fsahatsion, H., Aberra, M. and Sandip, B. (2013) Traditional Sheep Production and Breeding Practice in Gamogofa Zone, Southern Ethiopia. International Journal of Livestock Production Research, 1, 26-43.

[76] Getahun, L., Girma, A., Siegmund-Schultze, M., Valle, A. and Arate, Z. (2008) Small Ruminant Production in Two Mixed-Farming Systems of Southern Ethiopia: Status and Prospects for Improvement. Experimental Agriculture, 44, 399-412.

[77] Deribe, G. (2009) On-Farm Performance Evaluation of Indigenous Sheep and Goats in Alaba, Southern Ethiopia. MSc Thesis, Hawassa University, Awassa.

[78] Fekerte, F. (2008) On-Farm Characterization of Blackhead Somali Sheep Breed and Its Production System in Shinile and Erer Districts of Shinile Zone. MSc Thesis, Haramaya University, Haramaya.

[79] Aden, T. (2003) Evaluation of Local Sheep Breed under Traditional Management around Rural Areas of Dire Dawa. MSc Thesis, Alemaya University, Alemaya. 
[80] Dhaba, U., Belay, D., Solomon, D. and Taye, T. (2013) Breeding Practices and Reproductive Performance of Traditionally Managed Indigenous Sheep and Goat in Ilu Abba Bora Zone of Oromia Regional State, Ethiopia. Global Veterinaria, 10, 676-680.

[81] Drouilhet, L., Mansanet, C., Sarry, J., Tabet, K., Bardou, P., Woloszyn, F., Lluch, J., Harichaux, G., Viguie, C., Monniaux, D., Bodin, L., Mulsant, P. and Fabre, S. (2013) The Highly Prolific Phenotype of Lacaune Sheep Is Associated with an Ectopic Expression of the B4GALNT2 Gene within the Ovary. PLoS Genetics, 9, e1003809. https://doi.org/10.1371/journal.pgen.1003809

[82] Davis, G.H. (2005) Major Genes Affecting Ovulation Rate in Sheep. Genetics Selection Evolution, 37, 11-23. https://doi.org/10.1186/1297-9686-37-S1-S11

[83] Haresign, H. (1985) The Physiological Basis of Variation in Ovulation and Litter Size in Sheep. A Review. Journal Livestock Production Science, 13, 3-20. https://doi.org/10.1016/0301-6226(85)90075-2

[84] Ibrahim, H. (1998) Small Ruminant Production Techniques. ILRI Manual 3. ILRI (International Livestock Research Institute), Nairobi.

[85] Abegaz, S., Duguma, G., Negussie, E., Gelmesa, U., Terefe, F. and Rege, J.E.O. (2002) Factors Affecting Reproductive Performance and Estimates of Genetic Parameters of Litter Size in Horro Sheep. Journal of Agricultural Science, 139, 79-85. https://doi.org/10.1017/S0021859602002265

[86] Wilson, R.T. (1986) Livestock Production in the Central Mali: Long-Term Studies on Cattle and Small Ruminants in the Agro Pastoral System. ILCA Research Report No. 14.

[87] Musa, H.H., Suleiman, F.H., El amin, F.M., Chen, G.H., Mekki, D.M. and. Li, B.C. (2005) Evaluation of West African Sheep under Two Production Systems. Journal of Animal Veterinary Advances, 12, 971-975.

[88] Mukasa-Mugerwa, E., Lahlou-Kassi, A., Anindo, D., Rege, J.E.O., Tembely, S., Markos, T. and Baker, R.L. (2000) Between and within Breed Variation in Lamb Survival and the Risk Factors Associated with Major Causes of Mortality in Indigenous Horro and Menz Sheep in Ethiopia. Small Ruminant Research, 37, 1-12. https://doi.org/10.1016/S0921-4488(99)00152-2

[89] Hassen, Y., Sölkner, J. and Fuerst-Waltl, B. (2004) Body Weight of Awassi and Indigenous Ethiopian Sheep and Their Crosses. Small Ruminant Research, 55, 51-56. https://doi.org/10.1016/j.smallrumres.2004.01.008

[90] Lakew, M., Haile-Melekot, M. and Mekuriaw, G. (2014) Evaluation of Growth Perform Performance of Local and Dorper $\times$ Local Crossbred Sheep in Eastern Amhara Region, Ethiopia. Iranian Journal of Applied Animal Science, 4, 787-794.

[91] Thiruvenkadan, A.K., Karunanithi, K., Muralidharan, J. and Babu, R.N. (2011) Genetic Analysis of Pre Weaning and Post Weaning Growth Traits of Mecheri Sheep under Dry Land Farming Conditions. Asian-Australian Journal Animal Science, 24, 1041-1047. https://doi.org/10.5713/ajas.2011.10361

[92] Albial, A.M. and Sing, J. (2013) Environmental and Genetic Factors Affecting Early Growth Traits in Three Yemeni Indigenous Sheep Breeds. Iranian Journal of Applied Animal Science, 3, 105-112.

[93] Gizaw, G. (2002) Genetic Evaluation of Menz and Awassi x Menz Crossbred Sheep in Ethiopia. MSc Thesis, Karnal132001 (Haryana).

[94] Yilmaz, O., Denkb, H. and Bayram, D. (2007) Effects of Lambing Season, Sex and Birth Type on Growth Performance in Norduz Lambs. Small Ruminant Research, 68, 336-339. http://www.sciencedirect.com/science/article/pii/S0921448805004864 
https://doi.org/10.1016/j.smallrumres.2005.11.013

[95] Bathaei, S.S. and Leroy, P.L. (1997) Genetic and Phenotypic Aspects of the Curve Characteristics in Mehraban Iranian Fat-Tailed Sheep. Small Ruminant Research, 29, 261-269. https://doi.org/10.1016/S0921-4488(97)00142-9

[96] Belete, S. (2009) Production and Marketing Systems of Small Ruminants in Goma District of Jimma Zone, Western Ethiopia. Msc Thesis, Hawassa University, Awassa.

[97] Abegaz, S. and Duguma, G. (2000) Genetic and Phenotypic Parameters of Growth, Reproduction, and Survival Performance of Horro Sheep at Bako Agriculture Research Center. Research Report, International Livestock Research Institute (ILRI), Addis Ababa.

[98] Niftalem, D. (1990) On Farm Study of Reproductive and Growth Performance of Menz Sheep around Debre Brahan Area. M.Sc. Thesis, Alemaya University, Alemaya.

[99] Agyemang, K., Negussie, A., Voorthuizen, A. and Anderson, F.M. (1985) A Rapid Survey of Sheep Production in the Traditional Sector of Debre Berhan, Ethiopian Highlands. Small Ruminants in African Agriculture, Addis Ababa, 30 September-4 October 1985, 175-185.

[100] Abebe, M. (1999) Husbandry Practice and Productivity of Sheep in Lallo-Mama Midir Woreda of Central Ethiopia. MSc Thesis, Alemaya University, Alemaya.

[101] Dibissa, N. (2000) Sheep Production on Smallholder Farms in Ethiopian Highlands-A Farming System Approach. Doctoral Dissertation, Humboldt-University, Berlin.

[102] Wilson, R.T., Traore, A. and Mukasa Mugerewa, E. (1993) Mortality and Morbidity of African Small Ruminants under Various Management System. Patholegie Caprine et Productions, Niort, 26-29 June 1989, 208-236.

[103] Yacob, Y. (2008) Environmental and Genetic Parameters of Growth, Reproductive and Survival Performance of Afar and Blackhead Somali Sheep at Werer Agricultural Research Centre, Fellowship Report Submitted to International Livestock Research Institute (ILRI) and Ethiopian Institute of Agricultural Research (EIAR).

[104] Brännäng, E., Kurtu, M.Y. and Ido, D. (1987) Preliminary Report on Performance of Local and Crossbred Sheep at Assela Research Station, 1972-1985. Proceedings of the 1 st National Livestock Improvement Conference, Addis Ababa, 11-13 February 1987, 81-85.

[105] Alemayehu, S., Jembere, T. and Duguma, G. (2017) Study of Early Growth Traits in Horro Sheep Using Sizable Records at Bako Agricultural Research Center, West Ethiopia. Livestock Research for Rural Development, 29.

http://www.lrrd.org/lrrd29/2/alem29026.htm

[106] Demeke, S., van der Westhuizen, C., Fourie, P.J., Neser, F.W.C. and Lemma, S. (2004) Effect of Genotype and Supplementary Feeding on Growth Performance of Sheep in the Highlands of Ethiopia. South African Journal of Animal Science, 34, 110-112.

[107] Surafel, M., Zeleke, M., Solomon, G. and Mengiste, T. (2012) Community Based Characterization of Simen Sheep Based on Growth Performance and Farmers' Breeding Objectives in Simien Mountain Region Ethiopia. Research Journal of Animal Science, 6, 47-55. https://doi.org/10.3923/rjnasci.2012.47.55

[108] Yiheyis, A., Tegegn, F., H/Melekot, M. and Taye, M. (2012) Pre-Weaning Growth Performance of Sekota Sheep Breed in Waghimra Zone, Ethiopia. Online Journal Animal Feed Resource, 2, 340-343. 
[109] Nowak, R. and Poindron, P. (2006) From Birth to Colostrums: Early Steps Leading to Lamb Survival. Reproduction Nutrition Development, 46, 431-446. https://doi.org/10.1051/rnd:2006023

[110] Mukasa-Mugerwa, E., Said, A.N., Lahlou-Kassi, A., Sherington, J. and Mutiga, E.R. (1994) Birth Weight as Risk Factors for Prenatal Ewe Supplementation and Gestation Weight Gain in Ethiopian Menz Sheep. Preventive Veterinary Medicine, 19, 45-56. https://doi.org/10.1016/0167-5877(94)90014-0

[111] Schuurs, A.H.W.M. and Verheul, H.A.M. (1990) Effect of Gender and Sex Steroids on the Immune Response. Journal of Steroid Biochemistry, 35, 157-172. https://doi.org/10.1016/0022-4731(90)90270-3

[112] Norwak, R. (1990) Development of Mother Discrimination by Single and Multiple Newborn Lambs. Development in Psychobiology, 22, 833-845. https://doi.org/10.1002/dev.420220807

[113] Dwyer, C.M. (2003) Behavioral Development in the Neonatal Lamb: Effect of Maternal Birth Related Factors. Theriogenology, 59, 1027-1050.

https://doi.org/10.1016/S0093-691X(02)01137-8 